\title{
Sustainable Employment Opportunities in Governments in India and Public and Financial Sectors
}

\author{
Arif A. Waqif ${ }^{1,2}$, N. Ravinder Reddy ${ }^{3}$ \\ ${ }^{1}$ School of Management, University of Hyderabad, Hyderabad, India \\ ${ }^{2}$ Administrative Staff College of India, Hyderabad, India \\ ${ }^{3}$ The ICFAI School of Public Policy, ICFAI University, Hyderabad, India \\ Email: waqif.arif@gmail.com, nravinderreddy@gmail.com
}

Received 24 May 2015; accepted 12 September 2015; published 15 September 2015

Copyright (C) 2015 by authors and Scientific Research Publishing Inc.

This work is licensed under the Creative Commons Attribution International License (CC BY). http://creativecommons.org/licenses/by/4.0/

(c) (i) Open Access

\begin{abstract}
Thousands of annual employment opportunities are available in the Governments of India and states like former Andhra Pradesh, and the public and financial sectors. This paper summarizes the types of jobs available for fresh graduates by broad categories. It also explores emerging employment opportunities in India in specific selected public sectors, and the economy in general. It briefly outlines the minimum educational qualifications, entrance/application procedures, etc. for jobs in central and state governments. These are based on the relevant information available from various secondary sources and on relevant internet sites and public advertisements. It concludes with the suggestion that fresh graduates in India, encouraged by their teachers and employment counsellors, may need to explore more sustainable employment in government and public sectors.
\end{abstract}

\section{Keywords}

Sustainable Employment Opportunities, Central Indian Government Services, State Governments, Public Enterprises, Banking Sector, Make in India

\section{Introduction}

Most students, especially in engineering, management and other disciplines, aspire for employment in domestic and international private/corporate organizations. These aspirations are based primarily on peer group and parental expectations. This is at least partly because they are not equally aware of more sustainable employment opportunities in central and state governments and economic and financial public sectors. Such employment may offer lower salaries compared to the private sectors. But the procedures for recruitment, retention and pro- 
motion etc. are under prescribed norms, and guidance of the Union Public Service Commission and Ministry of Human Resource Development, or State Public Service Commissions [1]. In public economic and financial sectors, they are based on prescribed procedures by concerned central and state government departments and agencies. They are all more transparent and open to public and judicial scrutiny and accountability than in the private sectors. However, the Central Industrial Disputes Act (1947) provides "protection" against arbitrary dismissal to all "workers" who are not supervisors in private and public sectors, subject to laid down procedures—see e.g., Deakin \& Haldar, 2015 on Labour Law Reforms in general and on Dismissal Protection in India, 1970-2013, in particular [2].

\section{Government Sectors in India}

\subsection{Central Government Services}

Hundreds of employment opportunities for fresh graduates from universities and colleges are annually available in Indian Administrative Service, Indian Police Service, Indian Forest Service, Indian Revenue Service, Indian Foreign Service, Indian Economic Service, Indian Information Service, and in various Central Government ministries, departments and agencies. Furthermore, Central Government owned public enterprises (CPSUs) and banks (CPSBs) offer similar number of annual employment opportunities. Recruitments and promotions in the Central Services are as per the guidelines of Union Public service Commission. CPSUs and CPSBs have prescribed by their own governing boards.

\subsection{State Governments}

In the Government of Andhra Pradesh (bifurcated in 2015 into Telangana and Andhra Pradesh) general annual openings exist in various departments and agencies, starting with Deputy Collector (Group I), Municipal Commissioner (Group II), Junior Inspector (Group III), and various departments, e.g., Transport, Social Welfare, Medical and Health, Education, Judicial and many State-owned enterprises. Recruitments and promotions in the State Government are under the directions and guidance of State Public Service Commission and boards of State-owned enterprises.

All in all, the number of jobs annually available for fresh graduates and post-graduates in Central Government and State of Andhra Pradesh (now Telangana and Andhra Pradesh) alone may add to thousands. Similar number of annual employment opportunities exist in other States in India, and public enterprises and financial sectors.

Table 1 summarizes sector-wise employment opportunities in selected public and private sectors in India as of 2012 [3].

It is seen that employment in the organised sector-officially registered enterprises employing 20 or more workers-is less than 10 percent of the total labour force. But in the organised sector, nearly 77 per cent (35

Table 1. Sector-wise employment in India-millions, 2012.

\begin{tabular}{|c|c|c|c|}
\hline S. No. & Sector-wise employment in India & Millions & Percentage \\
\hline \multirow{6}{*}{ I } & Organised public sector & & \multirow{6}{*}{$(37.6 \%)$} \\
\hline & Central government & 2.52 & \\
\hline & State governments & 7.18 & \\
\hline & Quasi-governments & 5.8 & \\
\hline & Local bodies & 2.11 & \\
\hline & Sub-total & 17.6 & \\
\hline II & Organised industry and agriculture & 17.3 & $(36.9 \%)$ \\
\hline III & Organised private sector & 11.9 & $(25.4 \%)$ \\
\hline IV & Total organised sectors & 46.8 & $(100 \%)$ \\
\hline V & Total labour force & 484 & \\
\hline VI & Employment in unorganised sectors & 437.2 & (90.3\% of total labour force) \\
\hline
\end{tabular}

Note: Figures in brackets in I, II, III and IV are percentages to total employment in organised sectors. See Note at end on employment in unorganised sectors. 
millions) are employed in the public sectors, and only 25.4 percent (11.9 millions) in the private sector. It is important to note that employment in the organised public and private sectors also generates spill-over employment opportunities in the unorganised sector. In the absence of reliable estimate of this employment multiplier, if we assume 2, total employment in the organised sectors and forward and backward organised sectors could have been 19.4 per cent of the labour force (93.6 millions), leaving the rest (390.4 millions) for the unorganised sectors.

\section{Minimum Qualifications and Other Stipulations}

All applicants to Central and State government services-except Group IV, mostly manual workers-should have at least a Bachelor's degree in any discipline from an academic institution recognised by India's University Grants Commission, Association of Indian Universities, All-India Council of Technical Education, Medical Council of India, or other officially recognised professional accrediting agencies. Minimum age limits are generally in the early 20s. There are specified quotas for socio-economically disadvantaged communities like Scheduled Castes and Scheduled Tribes, Other Backward Classes, sometimes also for women and local/state populations.

There are also service or post-specific eligibility criteria, advertised application procedures, entrance tests and interviews as per Ministry of Human Resource Development, UPSC, and other concerned central organisations like CPSUs and CPSBs boards, and their counterparts at State levels.

Latest information on the relevant details can be accessed from the illustrative list of sources in Reddy and Waqif, 2010/2014, or relevant websites and media advertisements.

\section{Banking and Financial Sectors}

Banking sector in India is growing rapidly, more and more services adding to the banking services, such as insurance, pension, and other financial products. With Pradhan Mantri Jan Dhan Yojana (PMJDY), a financial inclusion programme launched by the Prime Minister of India on August 28, 2014, crores of new accounts for poor and low-income groups have been added to the existing ones [4].

On the day one itself, 1.5 crore accounts were opened, each account holder getting an accident insurance cover of Rs.1 lakh, and Rs.30,000 life insurance cover [5]. Never before in the history, no insurance company could sell 1.5 crore accident insurance policies and life insurance policies in a day.

Guinness World Records certified the incredible achievement as "The most bank accounts opened in 1 week as a part of financial inclusion campaign is 18,096,130 and was achieved by Department of Financial Services, Government of India (India) from 23 to 29 August 2014” [6]. As of 5 February 2015, the number of accounts reached 127.65 million [7]. Before the launch of the programme, there were only 684 million savings accounts for a population of 1.2 billion [8].

As the accounts have increased around 20 percent, there is a scope for increasing employment opportunities in the banking sector. If the employment opportunities increase in proportion to the accounts, for 7.25 lakh employees, the increase would be 1.45 lakhs [8]. No sector has seen such a rapid growth.

Unlike in the private sector banks, pay differentials are low and job security is high in the public sector banks. Clearly, these developments offer thousands of annual employment opportunities in the public financial sectors.

\section{Make in India}

"Make in India" is an initiative of the Government of India, launched on 25 September 2014 [9]. The initiative is focused on promoting innovation, and manufacturing in the country in the 25 sectors: automobiles, automobile components, aviation, biotechnology, chemicals, construction, defence manufacturing, electrical machinery, electronic systems, food processing, IT and BPM, leather, media and entertainment, mining, oil and gas, pharmaceuticals, ports, railways, renewable energy, roads and highways, space, textiles and garments, thermal power, tourism and hospitality, and wellness [10]. This initiative will not all help attract investments from abroad but also promote local investment, thus adding to employment opportunities. However, the prospects of increasing employment in manufacturing sector are likely to be adversely affected by relatively lower real cost of financial and physical capital compared to higher real cost of labour during the last two-three decades [11].

In line with the government initiate, according to Twelfth Five Year Plan (2012-2017), all sectors are expected to recover from the slump of 2012-2013, leading to job creation, as given in Table 2 [12]. 
As a part of Make in India, the Ministry of Defence inked \$3.4 billion deals, which would make India the global hub for the M777 howitzer to be exported to South America, Africa and Europe [13]. Under the aviation sector, the Government of India cleared the Airbus-Tata consortium's bid to replace the Indian Air Force's ageing fleet for Rs.11,930 crores, and six new BrahMos supersonic cruise missile systems at a cost of Rs.2700 crores for the Indian Navy [14].

Shipbuilding sector is also a major source of employment. Even though 95 percent of the foreign trade is done through the sea, only 10 percent is transported through Indian ships. The scenario is further bleak in the context of global shipping, where the stock of ships registered in India is just 1.1 percent. On the other hand, the share of foreign vessels in the Indian shipping market has increased from 60 percent in the 1980s to about 92 percent by 2009-2010. On the positive note, there is a huge potential for growth and job creation in the shipbuilding sector and it is expected "to achieve 5 per cent share of the global shipbuilding market and 10 per cent share in the global ship repair industry by 2020” [15] (Twelfth Five Year Plan, 2013, V.2, p. 108).

Apart from above employment opportunities in Government of India and Andhra Pradesh (now Telengana and Andhra Pradesh) the following projected investments in selected sectors will offer large number of jobs from India's $12^{\text {th }}$ Five Year Plan (2012-2017) in the infrastructure sectors Table 3 and in Renewable Energy Technologies (RET)—Table 3 below [16].

Sector-wise projected investments is rupees 11 trillion per annum, and rupees 5,500,000 crores, or 55 trillion, or USD 1 trillion over a period of 5 years. A conservative estimate of 1 job per the investment of rupees 1 million generates 11 million direct jobs and 16.5 million total jobs on applying a 1.5 job multiplier for backward and forward linkages sectors. Construction is a potentially high labour-absorbing activity. Even the direct demand for labour in renewable energy technologies—solar, biomass, wind-is expected to increase exponentially.

Table 2. Annual growth rate of GDP by industry of origin at constant (2004-2005) prices (unit: per cent).

\begin{tabular}{|c|c|c|c|c|c|c|}
\hline \multirow{2}{*}{ S. No } & \multirow{2}{*}{ Sector } & \multicolumn{5}{|c|}{ Twelfth plan period } \\
\hline & & 2012-2013 & 2013-2014 & 2014-2015 & 2015-2016 & 2016-2017 \\
\hline 1 & Agriculture, forestry and fishing & 2.0 & 4.5 & 4.5 & 4.5 & 4.5 \\
\hline 2 & Mining and quarrying & 1.0 & 5.0 & 7.0 & 7.0 & 8.5 \\
\hline 3 & Manufacturing & 2.2 & 6.0 & 8.5 & 9.5 & 9.5 \\
\hline 4 & Electricity, gas and water supply & 5.2 & 7.5 & 8.0 & 8.0 & 8.0 \\
\hline 5 & Construction & 8.0 & 8.0 & 8.5 & 10.0 & 11.0 \\
\hline 6 & Trade, hotels and restaurant & 5.5 & 6.0 & 8.0 & 8.7 & 8.7 \\
\hline 7 & Transport, storage and communication & 7.3 & 11.1 & 13.0 & 13.6 & 14.1 \\
\hline 8 & Financing, insurance, real estate and business services & 9.8 & 9.5 & 10.0 & 10.0 & 10.0 \\
\hline \multirow[t]{4}{*}{9} & Community, social and personal services & 7.3 & 7.2 & 7.2 & 7.2 & 7.2 \\
\hline & Total GDP & 5.8 & 7.3 & 8.5 & 9.0 & 9.2 \\
\hline & Industry $(2-5)$ & 4.0 & 6.6 & 8.4 & 9.4 & 9.8 \\
\hline & Services $(6-9)$ & 7.6 & 8.3 & 9.4 & 9.7 & 9.9 \\
\hline
\end{tabular}

Table 3. India's 12th five year plan.

\begin{tabular}{cccc}
\hline S. No. & Sector & Rupees in trillions & Share of construction (percent) \\
\hline 1 & Power & 13.5 & 38 \\
2 & Roads & 9.69 & 63 \\
3 & Railways & 5.19 & 78 \\
4 & Ports & 1.97 & 65 \\
5 & Airports & 0.87 & 70 \\
\hline
\end{tabular}


Based on averages of the ranges, expected increases in jobs in 1) Solar: 115 times; 2) Biomass: 3 times; 3) Wind: 1.1 times.

Total installed capacities in MWs in RET — solar, biomass, wind - expected by the Ministry of Non-Renewable Energy, Government of India, are 21,071 in 2012, 86,497 in 2017, and 59,250 in 2022. Manufacturing, construction and installation, operations and maintenance, and fuel processing are emerging types of jobs in RET sectors [17] (Table 4).

Based on averages of the ranges, expected increases in jobs are 1) Solar: 115 times; 2) Biomass: 3 times; and 3) Wind: 1.1 times.

More generally, Table 5 below indicates the overall potential of the Indian economy to generate employment opportunities.

As many sectors witness a spurt of growth, a need for 8 million management workers such as supervisors and above will arise by the year 2025 (Twelfth Five Year Plan, 2013, V.2, p. 69). The manufacturing sector alone will need more than 90 million people by the year 2022 [18]. Thus, millions of jobs annually will be available from the planned investments Government of India generally, and from projected growth in renewable energy technologies, during the coming years.

\section{Concluding Remarks}

The paper has outlined the large number of employment opportunities in government of India, Andhra Pradesh and other state governments, public sector and financial enterprises, infrastructural, energy and banking and financial sectors, and the Indian economy more broadly.

It remains to be seen whether such opportunities will also benefit those at the bottom of the economic and social pyramid in the unorganised sectors.

Table 4. Range of total existing and projected jobs—selected sectors, in numbers.

\begin{tabular}{ccccc}
\hline S. No. & Sector & Existing & $\mathbf{2 0 1 7}$ & $\mathbf{2 0 2 2}$ \\
\hline 1. & Solar & $2000-2700$ & $62,000-77,800$ & $188,000-357,500$ \\
2. & Biomass & $180,500-780,800$ & $289,500-1,317,000$ & $523,000-2,321,600$ \\
3. & Wind & $8900-38,300$ & $10,000-440,000$ & $13,650-60,060$ \\
\hline
\end{tabular}

Table 5. Sector-wise composition of India’s GDP expenditures, percent of GDP, and estimated workforce-2013-2014.

\begin{tabular}{|c|c|c|c|c|c|}
\hline \multirow{3}{*}{$\mathbf{I}$} & a) & Total GDP expenditures & \multicolumn{3}{|l|}{ Rs.99,211,000 million } \\
\hline & b) & Estimated working population & \multicolumn{3}{|l|}{500 million } \\
\hline & c) & GDP/worker (a/b) : & \multicolumn{3}{|l|}{ Rs.198,422 million } \\
\hline & & \multicolumn{4}{|c|}{ Sector-wise expenditures and estimated employment } \\
\hline & & Sector & Expenditure (rupees in millions) & Percent & Estimated employment (in millions) \\
\hline \multirow{5}{*}{ II } & a) & Public administration etc. & $12,401,000$ & 12.5 & 57 \\
\hline & b) & Gross capital formation & $30,502,360,000$ & 30.7 & 154 \\
\hline & c) & Electricity, gas, water supply & 72,300 & 2.3 & 11.6 \\
\hline & d) & Private final consumption & $537,941,000$ & 57.5 & 272 \\
\hline & \multicolumn{4}{|c|}{ Total estimated workforce } & 494.6 \\
\hline & \multicolumn{5}{|c|}{ Social and infrastructural sectors } \\
\hline & & Sector & Expenditure (rupees in millions) & Percent & Estimated employment (in millions) \\
\hline \multirow{3}{*}{ III } & a) & Education & $3,075,541$ & 3.1 & 15.5 \\
\hline & b) & Health & $1,289,743$ & 1.3 & 7.15 \\
\hline & c) & Transport & $6,051,771$ & 6.1 & 31 \\
\hline
\end{tabular}




\section{Note}

Employment in unorganised sectors in India comprises millions of land-owning and tenant farmers, landless agricultural labourers, migrant construction and related workers, workers in tiny and household enterprises and small businesses, other self-employed workers including semi-skilled artisans, household helpers, etc.

\section{References}

[1] Reddy, R.N. and Waqif, A.A. (2010/2014) Secure Jobs. Mutual Assistance for Voluntary Institutions, Nizam’s Charitable Trust, Hyderabad. www.muavin.org

[2] Deakin, S. and Haldar, A. (2015) How Should India Reform Its Labour Laws. Economic and Political Weekly, L12, 448-455. http://dx.doi.org/10.2139/ssrn.2601039

[3] Ministry of Finance, Government of India (2015) Trends in Employments in India. Economic and Political Weekly, 1, 91. (Based on Economic Survey, 2014-15.)

[4] Prime Minister's Office (2014) PM’s Email to All Bank Officers. Press Information Bureau, Government of India. http://pib.nic.in/newsite/erelease.aspx?relid=109051

[5] Mehra, P. (2014) PM Banks on Mega Plan to Fight Debt. The Hindu. http://www.thehindu.com/news/national/modi-launches-pradhan-mantri-jan-dhan-yojana/article6360402.ece

[6] Lynch, K. (2015) India Makes Financial World Record as Millions Open New Bank Accounts. Guinness World Records.

http://www.guinnessworldrecords.com/news/2015/1/india-makes-financial-world-record-as-millions-open-new-bank-a ccounts

[7] Kaushal, A. (2015) Nearly Every Indian Household Has a Bank Account. Business Standard. http://www.business-standard.com/article/current-affairs/nearly-every-indian-household-has-a-bank-account-11502110 1677_1.html

[8] Mehra, P. (2014) PM Banks on Mega Plan to Fight Debt. The Hindu. http://www.thehindu.com/news/national/modi-launches-pradhan-mantri-jan-dhan-yojana/article6360402.ece

[9] Mehra, P. (2014) “Make in India” Pitch from Sept. 25. The Hindu. http://www.thehindu.com/business/Economy/modi-to-launch-make-in-india-campaign-on-sep-25/article6422804.ece

[10] Make in India. http://www.makeinindia.com/sectors/

[11] Sen, K. and Das, D.K. (2015) Where Have All the Workers Gone? Puzzle of Declining Labour Intensity in Organised Indian Manufacturing. Economic and Political Weekly, L23.

[12] Planning Commission, Government of India (2013) Twelfth Five Year Plan (2012-2017): Faster, More Inclusive and Sustainable Growth, Vol. 1, SAGE Publications India Pvt Ltd., New Delhi, 42.

[13] Pubby, M. (2015) Make in India: Defence Ministry Okays \$3.4 Billion Deals including Procurement of US-Origin M777 Artillery Guns. The Economic Times.

http://economictimes.indiatimes.com/news/defence/make-in-india-defence-ministry-okays-3-4-billion-deals-includingprocurement-of-us-origin-m777-artillery-guns/articleshow/47274605.cms

[14] PTI (2015) Government Nod to Rs 11,930 Crore Airbus-Tata Consortium Bid to Replace Avro Fleet. The Economic Times.

http://economictimes.indiatimes.com/news/defence/government-nod-to-rs-11930-crore-airbus-tata-consortium-bid-to-r eplace-avro-fleet/articleshow/47272470.cms

[15] Planning Commission, Government of India (2013) Twelfth Five Year Plan (2012-2017): Economic Sectors, Vol. 2, SAGE Publications India Pvt Ltd., New Delhi, 108.

[16] Planning Commission, Government of India (2013) Twelfth Five Year Plan (2012-2017): Economic Sectors, Vol. 2, SAGE Publications India Pvt Ltd., New Delhi, 69.

[17] Jain, M. and Patwardhan, A. (2013) Employment Outcomes of Renewable Energy Technologies: Implications of Policies in India. Economic and Political Weekly, XLVIII, 84-89.

[18] Planning Commission, Government of India (2013) Twelfth Five Year Plan (2012-2017): Economic Sectors, Vol. 2, SAGE Publications India Pvt Ltd., New Delhi, 70. 